\title{
Perancangan User Experience Website Profil Dengan Metode The Five Planes (Studi kasus: BP3K Kecamatan Mundu)
}

\author{
Luthfi Hardiansyah $^{1}$, Khalid Iskandar*², Harliana ${ }^{3}$ \\ ${ }^{1}$ Teknik Informatika, STIKOM Poltek Cirebon, Indonesia \\ ${ }^{* 2}$ Managemen, Universitas Muhadi Setiabudi, Brebes, Indonesia \\ ${ }^{3}$ Teknik Informatika, Universitas Muhadi Setiabudi, Brebes, Indonesia \\ e-mail correspondence: *2khalid.iskandar@umus.ac.id
}

\begin{abstract}
Abstrak
User experience merupakan salah satu faktor penting yang dapat mendukung keberhasilan dalam membangun suatu website. Website yang baik adalah website yang mempertimbangkan dan memperhatikan kemudahan pengguna, sehingga tidak menyebabkan kesulitan bagi pengguna ketika mengakses website tersebut. Saat ini penyampaian dan penyebaran informasi penyuluhan di BP3K Mundu masih sering terjadi kesalahan dalam memahami komunikasi yang diterima. Selain itu tampilan lama website BP3K Mundu masih belum tersusun dengan baik, sehingga pemanfaatan website belum maksimal. Penelitian ini mengajukan perancangan website profil sekaligus memperhatikan aspek user experience menggunakan metode the five planes. Metode ini terdiri dari beberapa lapisan, yaitu strategy plane, scope plane, structure plane, skeleton plane, dan surface plane. Hasil penelitian ini berupa perancangan prototipe website profil yang dilakukan sampai tahap high fidelity. Dalam proses evaluasi dilakukan pengujian terhadap tiga pengguna berdasarkan lima aspek usability yang menghasilkan nilai $86,22 \%$ pertanyaan yang mampu di jawab, dan 13,77\% pertanyaan yang tidak dapat terjawab. Hasil pengujian menunjukkan bahwa website profil memiliki tingkat usability yang sangat baik sehingga bisa diterima dan siap digunakan oleh pengguna dengan fitur yang tersedia.
\end{abstract}

Kata kunci-User Experiance, Website, The Five Planes, Usablility Testing

\begin{abstract}
User experience is one of the important factors that can support the success in building a website. A good website must consider and pay attention to its users, so as not to cause difficulties for users in the use of the website. Currently BP3K Mundu in delivery and distribution of information outreach is still often the case wrong communications. In addition the look of old website BP3K Mundu is still not arranged properly, so that the maximum utilization of the website yet. The study proposed the design of the website profiles at once noticed aspects of the user experience using the method of the five planes. This method consists of several layers, i.e. the strategy scope plane, plane, plane, plane skeleton structure, and surface plane. The results of this research in the form of the design of the prototype website profiles done to stage the high fidelity. In the evaluation process carried out testing against three users based on five aspects of usability that generate value $86.22 \%$ questions answered, capable and $13.77 \%$ of the questions could not be answered. The test results indicate that the website profile has an excellent usability level so that it can be accepted and ready to be used by users with the features available.
\end{abstract}

Keywords - Userr Experiance, Website, The Five Planes, Usablility Testing

Submitted: 17April 2019, Accepted: 29 April 2019, Published: Mei 2019

ISSN: 2685-4902 (online), Website: http://jurnal.umus.ac.id/index.php/intech 


\section{PENDAHULUAN}

Pembangunan user experience (UX) telah mendapatkan perhatian yang amat penting dalam dunia masa kini. Dimana user experience dapat mendukung keberhasilan dalam membangun suatu website, karena masih berkaitan dengan satu hal, yaitu bagaimana pengguna merasakannya[1]. UX memastikan bahwa website yang dibuat dapat memenuhi kebutuhan dan dapat digunakan oleh pengguna dengan pengalaman yang menyenangkan. Jika suatu website yang digunakan tidak dirancang dengan memperhatikan aspek user experience yang baik, mengakibatkan kebutuhan dari pengguna dalam menggunakan website tersebut menjadi tidak terpenuhi. Saat ini BP3K Mundu dalam penyampaian dan penyebaran informasi penyuluhan dilakukan melalui metode langsung dan tidak langsung. Metode langsung yang dimaksud adalah dengan melalui temu karya, temu usaha, dan temu lapang. Sedangkan metode tidak langsung dilakukan dengan melalui penyebaran brosur, surat edaran, siaran radio, pemutaran film/slide dan juga website. Namun dalam penyampaian dan penyebaran informasi tersebut, masih sering terjadi miscommunication (salah komunikasi) antara pihak pelaksana penyuluh dengan para petani dalam memperoleh layanan dan informasi terkait program dan kegiatan penyuluhan. Hal tersebut disebabkan karena informasi yang dikirimkan oleh pihak pelaksana penyuluh untuk desa tidak sampai kepada petani. Dengan begitu petani yang tidak mengetahui informasi tersebut, menjadi tidak mengikuti kegiatan penyuluhan dan berdampak pada intensitas penyuluhan menjadi berkurang. Selain itu penyampaian dan penyebaran informasi melalui media website yang terlebih dahulu sudah ada dirasa masih belum optimal dan kurang mendukung, masih banyak fitur dan konten yang seharusnya ada dan dibutuhkan namun belum tersedia pada website, sehingga membuat petani masih sulit untuk mencari suatu informasi yang diinginkan dan menjadi pertimbangan bagi petani dalam menggunakan website tersebut. Hasil pengamatan yang penulis lakukan pada website, dalam hal konten (isi informasi) yang dikelola masih sangat terbatas dan belum tersusun/terorganisasikan dengan baik. Terdapat juga informasi yang letaknya berbeda (tidak mengelompok), daftar kategori (label) masih belum tertata rapi, dan tidak tersedianya tombol mesin untuk pencarian. Selain itu dari segi penggunaan teks, gambar dan warna masih tidak selaras/konsisten.

Oleh karena itu, untuk mengatasi masalah tersebut, dan menghindari terjadi salah komunikasi dalam penyampaian dan penyebaran informasi, maka perlu dilakukan perbaikan dan pengembangan website sebagai alternatif pelayanan publik, sehingga dapat membantu masyarakat khususnya bagi para petani dalam mendapatkan layanan dan informasi terkait program dan kegiatan penyuluhan yang dapat diakses melalui website. Untuk mewujudkan hal tersebut, dalam merancang suatu website agar sesuai dengan kebutuhan penggunanya, maka aspek user experience sangat penting dan harus dipertimbangkan, sehingga tidak menyebabkan kesulitan bagi pengguna dalam berinteraksi dengan website tersebut. Dengan memperhatikan UX, website yang dirancang dapat lebih efektif dalam menetapkan tujuan-tujuan berdasarkan kebutuhan pengguna[2] Dalam hal ini, di mana perilaku pengguna sangat dipengaruhi oleh tata letak desain website, baik itu untuk kemudahan akses antar menu dan halaman, maupun tampilan gambar dan ikon sebagai petunjuk yang mudah dimengerti.

Metode User Experiance pernah diterapkan pada analisis dan perancangan website profile untuk perusahaan therapie, dimana dengan metode ini dapat memudahkan dalam menemukan permasalahan dan mendapatkan solusi dalam proses perancangan website yang sesuai dengan keinginan perusahaan, karena metode ini mementingkan interaksi manusia dan komputer, sehingga dapat menganalisis sifat website yang akan dirancang, selain itu metode User Experiance juga dapat memberikan kemudahan dan kenyamanan untuk para pengunjung website[3]. Selain itu kemudahan saat pengguna berinteraksi dengan User Interface (UI) dari website dalam rangka memenuhi UI yang sesuai kebutuhan pengguna diperlukan pendekatan untuk mengetahui karakteristik dari pengguna, melalui penerapan metode paper prototyping, dengan teknik wireframe mampu mengidentifikasi masalah pengguna dan rekomendasi dari konsumen langsung sekaligus merekam model UX yang ada, selain itu 
metode paper prototyping yang digunakan dapat menciptakan sebuah pengalaman yang menyenangkan dalam UI[4]

Metode User Experiance (UE) juga dapat dimanfaatkan untuk pengembangan aplikasi repository karya ilmiah LIPI berbasis mobile, dimana Aplikasi dibangun dengan memerhatikan aspek pengalaman pengguna sehingga fungsi dan tampilan sesuai dengan harapan responden. Pada tahapan akhir dilakukan pengujian Repositori LIPI yang telah dibangun dengan metode think aloud[5]. Penelitian lain adalah mengenai kehadiran ponsel pintar (smartphone) dalam mengakses suatu web telah membuat perubahan dalam penggunaan internet. Banyak orang sekarang menggunakan perangkat mobile untuk melakukan browsing. Namun ukuran layar yang bervariasi dari suatu perangkat mobile berpengaruh pada pengalaman pengguna (user experience), karena konten web pada perangkat mobile bervariasi dalam ukuran dan navigasi halamannya. Hadirnya desain web responsif, merevolusi cara halaman web yang dirancang dan cara penggunaannya. Desain web responsif membuat halaman web menyesuaikan ukuran layar pada jenis perangkat apa pun. Penelitian ini bertujuan untuk mengevaluasi efek dari desain web responsive pengalaman pengguna pada e-Ebola Awareness System dalam perangkat laptop dan smartphone. Dari data yang dikumpulkan dan dianalisis, hasil didapatkan bahwa pengguna memiliki pengalaman pengguna yang lebih baik dengan smartphone dibanding dengan laptop saat menggunakan sistem, namun untuk sebagian besar, pengalaman pengguna dengan dua jenis perangkat tidak signifikan berbeda pada tingkat kepercayaan 95\%, bahwa untuk metrik tersebut, jaringan responsive desain memiliki efek yang sama terhadap pengalaman dan sikap pengguna [6].

Setiap perangkat mobile memiliki ukuran layar yang berbeda sehingga cara pendekatan dalam desainnya pun berbeda supaya konten yang tampil pada layar mobile akan terlihat dengan sempurna. Dengan jenis ukuran layar yang berbeda seperti di ponsel, smartphone, tablet, komputer pc dan laptop sehingga setiap situs yang tampil akan selalu berubah. Dalam penelitian ini bertujuan untuk mengukur kualitas pengalaman pengguna desain web responsif pada perangkat mobile. Dengan melakukan pengumpulan data 156 mahasiswa di Universitas Indonesia, responden diminta untuk mengevaluasi pengalaman pengguna desain web pada salah satu skenario yaitu desain web responsif pada tampilan desktop dan perangkat mobile serta desain web tidak responsif pada perangkat mobile. Kualitas pengalaman pengguna dalam penelitian ini diukur dengan melihat jumlah klik dan gulungan (scroll) serta kualitas informasi yang telah dialami oleh pengguna. Hasil dari uji ANOVA yang dilakukan, terbukti bahwa desain web responsif mampu mempertahankan pengalaman pengguna terhadap kualitas website pada fungsi beranda, keterbacaan konten, dan kenyamanan penggunaan website, namun tidak pada arsitektur informasinya. Selain itu, desain web responsif juga terbukti mengurangi jumlah scrolling ketika membaca konten. Namun desain web responsive diperlukan lebih banyak scroll dan klik daripada yang tidak responsif ketika menjelajahi arsitektur informasinya[7]

\section{METODE PENELITIAN}

Penelitian ini dilaksanakan guna menganalisa dan merancang sebuah perancangan website profil baru, oleh karena itu gambaran profil perusahaan yang sedang di amati dalam hal ini BP3K Kecamatan Mundu sebagai objek penelitian, agar nantinya perancangan baru yang akan diterapkan sesuai dengan harapan. Metode pengembangan perangkat lunak yang digunakan adalah the five planes user experience elements.

a. User Experiance (UE)

Pada dasarnya pengalaman pengguna merupakan istilah pengalaman pengguna dalam merasakan suatu kemudahan dan efisiensi dalam interaksi manusia dengan komputer. Termasuk persepsi seseorang mengenai aspek-aspek praktis seperti kegunaan, kemudahan penggunaan, dan efisiensi dari sebuah sistem yang ada[8]. 
b. Komponen inti dalam User Experiance (UE)

Dalam user experience (UX) design terdapat 6 komponen penting yang perlu diketahui, yakni usability, interaction design, visual design, information architecture, content strategy, dan user research. Dengan memahami keenam komponen itu, maka dapat membantu menerapkan UX design dengan baik sehingga membuat suatu produk unggul dibandingkan dengan produk lainnya[8]

1) User research

User research adalah tindakan mewawancarai pengguna prospektif atau user candidate dan pengguna aktual dari sebuah website untuk mendapatkan kejelasan pada sejumlah tujuan. Dengan melakukan user research, dapat membantu mengetahui kelemahankelemahan yang ada dalam website sebelum diluncurkan. Selain itu, dapat menguatkan potensi website sehingga tujuan pembuatan website itu dapat tersampaikan pada penggunannya[8]

2) Content strategy

Komponen penting lainnya yang tak boleh dilewatkan ialah content strategy. Komponen ini sangat penting karena content strategy berfokus pada perencanaan, pembuatan, pengiriman, dan tata kelola konten suatu website. Tujuan dari content strategy ini adalah menciptakan konten yang bermakna, menarik, dan berkelanjutan. Dengan begitu, pengguna akan tertarik dan dapat bertahan menggunakan website yang dibuat[8]

3) Information architecture

Arsitektur Informasi merupakan komponen user experience design (desain pengalaman pengguna) yang tidak boleh terlupakan. Arsitektur informasi adalah penciptaan struktur informasi dalam suatu produk agar mudah dimengerti oleh penggunanya. Komponen arsitektur informasi memudahkan pengguna ketika menggunakan website sehingga pengguna dapat menggunakan website itu dengan maksimal[8]

4) Interaction design

Interaction design merupakan desain interaksi antara pengguna dengan suatu website. Tujuan utama interaction design ialah agar memudahkan pengguna saat menggunakan website tanpa harus merasa kebingungan atau kesulitan[8]

5) Visual design

Ketika sudah merancang interaksi seperti apa yang dikehendaki dalam produk, komponen selanjutnya yang tak kalah penting ialah visual design. Dalam komponen ini, perlu diperhatikan berbagai elemen tampilan visual mulai dari garis, rupa, pilihan warna, tekstur visual, tipografi, hingga bentuk tampilan animasi ataupun visual tiga dimensi. Masing-masing elemen itu harus bisa memberikan kenyamanan saat pengguna berinteraksi dengan website yang dibuat[8]

6) Usability

Ketika menerapkan UX design dalam merancang suatu website, hal pertama yang harus diperhatikan ialah komponen usability. Pengertian dari usability adalah sejauh mana sebuah website dapat digunakan oleh pengguna tertentu untuk mencapai tujuan tertentu secara efisien, efektif, dan pengguna menjadi puas saat menggunakan website tersebut.

Berdasarkan hasil penelitian, maka gambaran flowchart tahapan penelitian yang dilakukan terdapat pada Gambar 1. 


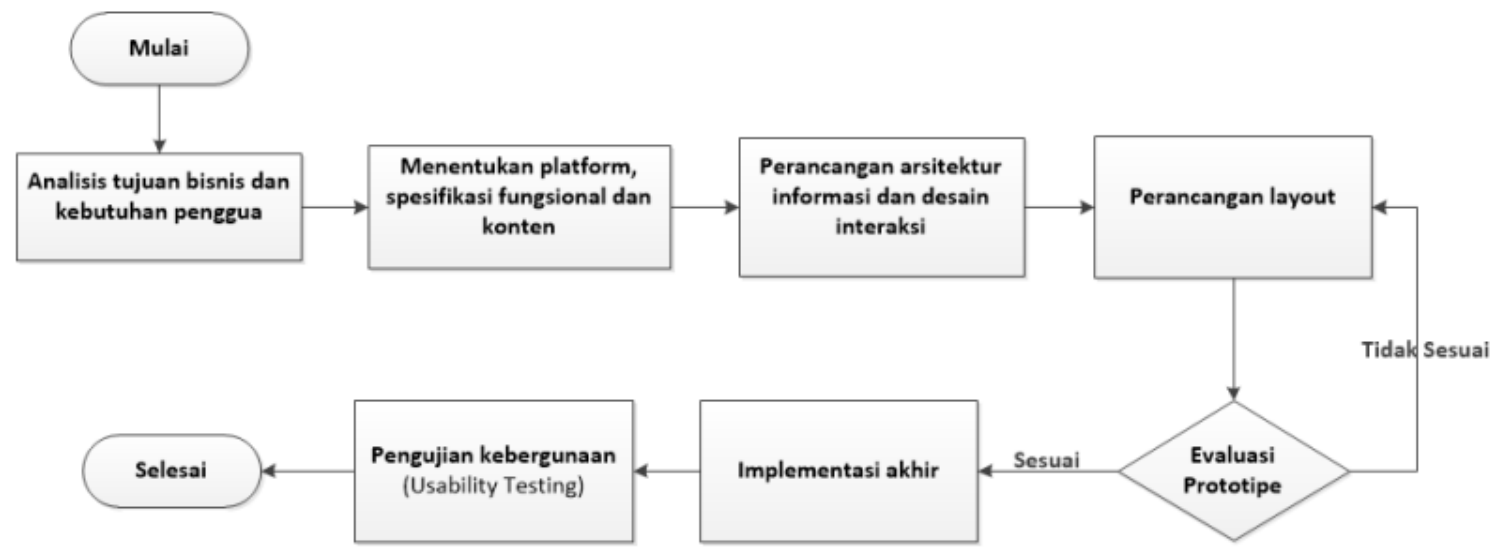

Gambar 1. Flowchart tahapan penelitian

\section{HASIL DAN PEMBAHASAN}

Pada penelitian ini, penulis menerapkan metode the five planes ke dalam perancangan website yang terdiri 5 lapisan yaitu strategy plane, scope plane, structure plane, skeleton plane, dan surface plane dengan penjelasan dari lapisan tersebut sebagai berikut:

\section{The Strategy Plane (Bidang Strategi)}

Pada tahap ini telah dilakukan observasi dan analisis terkait dengan:

a) data wawancara

Pertanyaan-pertanyaan yang diajukan terbagi menjadi 3 bagian yaitu tentang penyampaian dan penyebaran informasi terkait program dan kegiatan penyuluhan yang telah berjalan, penggunaan teknologi dan internet, serta harapan terhadap website profil yang akan dibuat.

b) tujuan pengembangan website (product objective) dari stakeholder,

Dari wawancara yang dilakukan, pihak stakeholder membutuhkan website yang dapat membantu dalam mengelola berbagai data dan informasi penyuluhan yang relevan dan tepat waktu. Sesuai kebutuhan stakeholder akan dibuat suatu website profil yang dapat berfungsi sebagai media komunikasi dan publikasi informasi bagi petani dan masyarakat umum lainnya yang dapat diakses di mana saja dan kapan saja, sehingga dapat meningkatkan daya tarik serta minat masyarakat dalam mengakses website tersebut, serta meningkatkan kualitas layanan, khususnya dalam hal penyampaian dan penyebaran informasi penyuluhan.

c) kebutuhan pengguna (user needs) dan

Dari beberapa pertanyaan kuesioner (Lampiran 1) yang telah disebarkan ke 20 responden yaitu kepada 10 penyuluh dan 10 petani, didapatkanlah beberapa jawaban yaitu: responden membutuhkan suatu website profil yang menarik, informatif dan komunikatif. Tampilan website yang sederhana, mudah digunakan dan bisa dibuka via perangkat mobile (ramah seluler). Struktur pada menu dan halaman dapat ditemukan dengan mudah, serta dapat dikuti oleh mata pembaca (tampilan teks tulisan tidak terlalu kecil). Memiliki konten dan fitur yang tepat guna, serta mengurangi konten atau elemen yang tidak perlu (pop up, dan animasi yang berlebihan).

d) perancangan persona (user persona).

Berdasarkan hasil analisis penentuan tokoh persona, Nur Duniati merupakan salah satu responden penyuluh pertanian muda yang mengharapkan adanya layanan dan informasi secara online. Nur memiliki kemampuan dalam menggunakan laptop dan internet yang baik. Nur menggunakan fasilitas internet setiap hari dan memprioritaskan penggunaan internet untuk mengakses e-mail, berita, men download file dan jejaring sosial. Selain itu 
Nur cukup mahir dalam mengakses suatu situs web. Persona yang telah dibuat selengkapnya dapat dilihat pada Gambar 2.

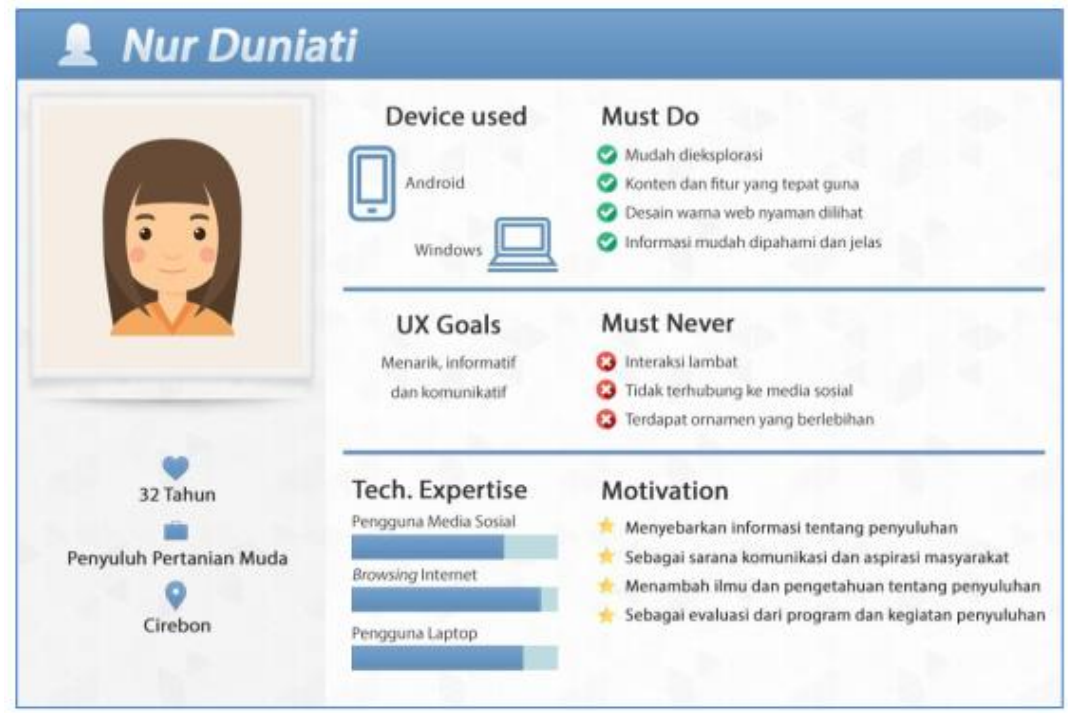

Gambar 2. User persona website profil BP3K Mundu

\section{The Scope Plane (Bidang Lingkup)}

Pada tahapan ini, ditentukan:

a) Platform dan device perangkat yang digunakan

Website Profil BP3K Mundu ini dikembangkan dengan menggunakan beberapa perangkat lunak. Berikut perangkat lunak yang digunakan untuk implementasi, antara lain: Xampp versi 3.2, Microsoft Office Visio 2010, Adobe Photoshop CS5, dan Framework Codeigniter 3.

b) Skenario penggunaan

Isi skenario memuat proses yang harus dilalui oleh pengguna dalam memenuhi tujuannya. Berikut adalah skenario yang telah dibuat berdasarkan karakter pada persona. Nur Duniati merupakan salah satu penyuluh pertanian muda yang berusia 42 tahun dan berdomisili di Cirebon. Nur Duniati berniat untuk menyebarkan informasi penyuluhan agar informasi tersebut dapat dikenal khalayak dan membantu masyarakat khususnya petani dalam mendapatkan layanan dan informasi penyuluhan. Biasanya para petani hanya mendapatkan informasi pada saat ada kegiatan atau pelatihan penyuluhan saja, dan sering tidak tepat waktu dalam proses penyampaiannya, dikarenakan para penyuluh menyesuaikan dengan jadwal petani yang terkadang memiliki kesibukan lain.

Selain itu brosur atau surat edaran yang disebarkan pun masih sangat terbatas, baik dalam hal desain dan informasinya. Adapun dalam pelaksanaan pelatihan penyuluhan, petani tidak diberikan file materi atau buku panduan tentang penyuluhan. Oleh karena itu Nur berinisiatif untuk menyebarkan informasi penyuluhan seputar program dan kegiatan penyuluhan. Akan tetapi, Nur belum dapat mengelola website tersebut dengan optimal, banyak kendala dan kesulitan yang dialami oleh Nur ketika mengelola halaman webnya. Akhirnya website tersebut belum dapat digunakan dengan baik oleh Nur dalam penyampaian dan penyebaran informasi penyuluhan. Untuk itu Nur membutuhkan suatu website profil yang dapat dikemas secara menarik, sehingga bias dimanfaatkan petani atau masyarakat lainnya dalam mendapatkan layanan dan informasi penyuluhan dengan mudah tanpa harus datang langsung ke kantor BP3K Mundu atau menunggu pihak penyuluh mengunjungi ke rumah-rumah petani. Dengan begitu, harapan Nur dengan adanya website profil tersebut dapat mendukung pengembangan program dan kegiatan penyuluhan menjadi lebih baik.

c) Spesifikasi fungsional dari setiap fitur yang dikembangkan 
Hasil wawancara dan penyebaran kuesioner kemudian dianalisis lebih lanjut untuk mendapatkan spesifikasi fungsionalitas yang menjadi kebutuhan aktivitas pengguna ketika menjalankan website. Spesifikasi fungsional dari fungsi utama yang sudah didapat adalah: login, dashboard CMS, profil kami, index berita, pencarian, slide show, publikasi, galeri, download dll

\section{The Structure Plane (Bidang Struktur)}

Pada tahap ini dirancang arsitektur informasi dengan pembuatan struktur website yang dapat dilihat pada Gambar 3. Struktur website ini dibangun dengan menu yang telah didefinisikan pada tahap sebelumnya yaitu scope plane, lalu meng-kategorikan beberapa fungsi halaman yang telah ditetapkan dalam perancangan.

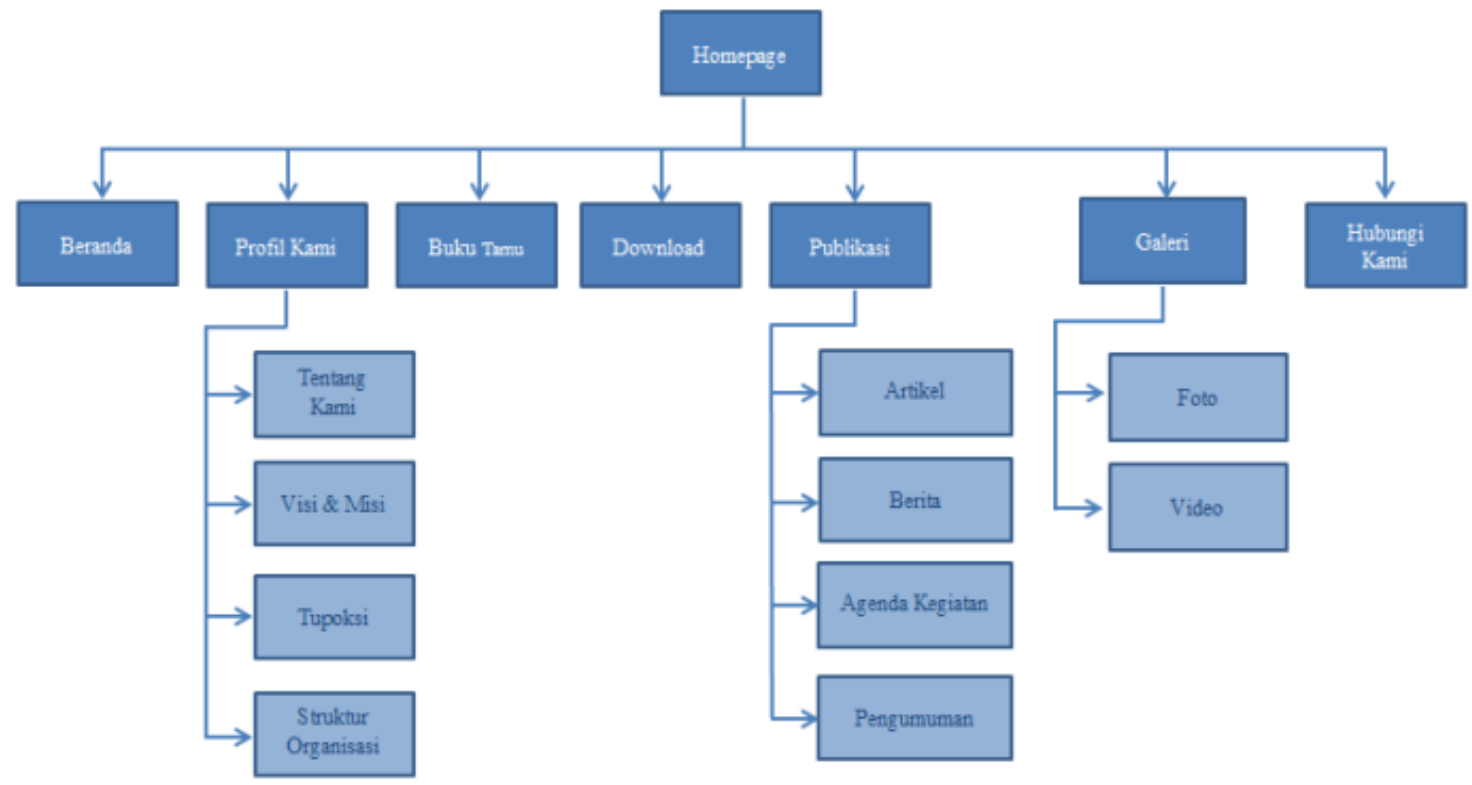

Gambar 3. Struktur website profil BP3K Mundu

Kemudian dilanjutkan dengan pembuatan desain interaksi, dalam penelitian ini penulis menggunakan Hierarchical Task Analysis (HTA). Dimana HTA ini mampu menggambarkan interaksi antara pengguna task yang dibuat kemudian disesuaikan dengan spesifikasi fungsional

\section{The Skeleton Plane (Bidang Rangka)}

Pada tahap ini dilakukan perancangan 25 wireframe antarmuka Website Profil BP3K Mundu yang memungkinkan untuk diterapkan pada perancangan website. Target utama dari tahap ini adalah perancangan prototipe low fidelity yang merupakan perwujudan dari desain interaksi pada tahap structure plane. Perancangan layout pada wireframe menyesuaikan dengan keinginan stakeholder yang didapat dari hasil wawancara. Prototipe low fidelity ini fokus terhadap perancangan antarmuka website yang meliputi penempatan elemen-elemen seperti penempatan tombol, elemen kontrol, foto, dan blok teks. Dalam perancangan prototipe low fidelity terdapat evaluasi guna mendapatkan umpan balik pengguna yang kemudian disusun menjadi requirements perbaikan website. Evaluasi prototipe diperoleh dengan meminta responden untuk menjawab pertanyaan yang berkaitan dengan desain dan fitur prototipe website. Berdasarkan requirements perbaikan di tahap sebelumnya, maka dilakukan beberapa perbaikan pada level prototipe high fidelity yang berupa antarmuka website (hand-coded prototype). Evaluasi prototipe pada level low fidelity ini masing-masing dilakukan sebanyak satu kali

\section{The Surface plane (Bidang Permukaan)}

Pemilihan kombinasi warna pada Website BP3K Mundu adalah warna hijau (\#5A9E25), abu-abu tua (\#363635) dan abu-abu muda (\#E8E8E8). Warna hijau digunakan sebagai warna utama dari tampilan website. Warna hijau melambangkan pertumbuhan, kesegaran, dan 
harapan. Untuk pemilihan font menggunakan Titillium web dan Source Sans Pro. Tema desain dan User Interface (UI) dibuat sederhana dengan sedikit kombinasi warna dan latar belakang berwarna putih agar mempermudah pengguna dalam menggunakan website[9].

Selanjutnya, dibuat hand-coded prototype dengan menggunakan framework Codeigniter dan Bahasa pemrograman PHP, CSS.

6. Usability Testing (Pengujian Kebergunaan)

Pengujian kebergunaan (usability testing) merupakan salah satu evaluasi terhadap suatu perangkat lunak aplikasi untuk mengetahui seberapa besar kemudahan suatu antarmuka (interface) dapat digunakan oleh pengguna saat berinteraksi dengan system. Tujuan dari usability testing ini untuk mengindentifikasi permasalahan usability yang dapat mempengaruhi interaksi system (perangkat lunak) dengan pengguna pada hasil perancangan website. Tahapan yang dilakukan pada proses usability testing adalah:

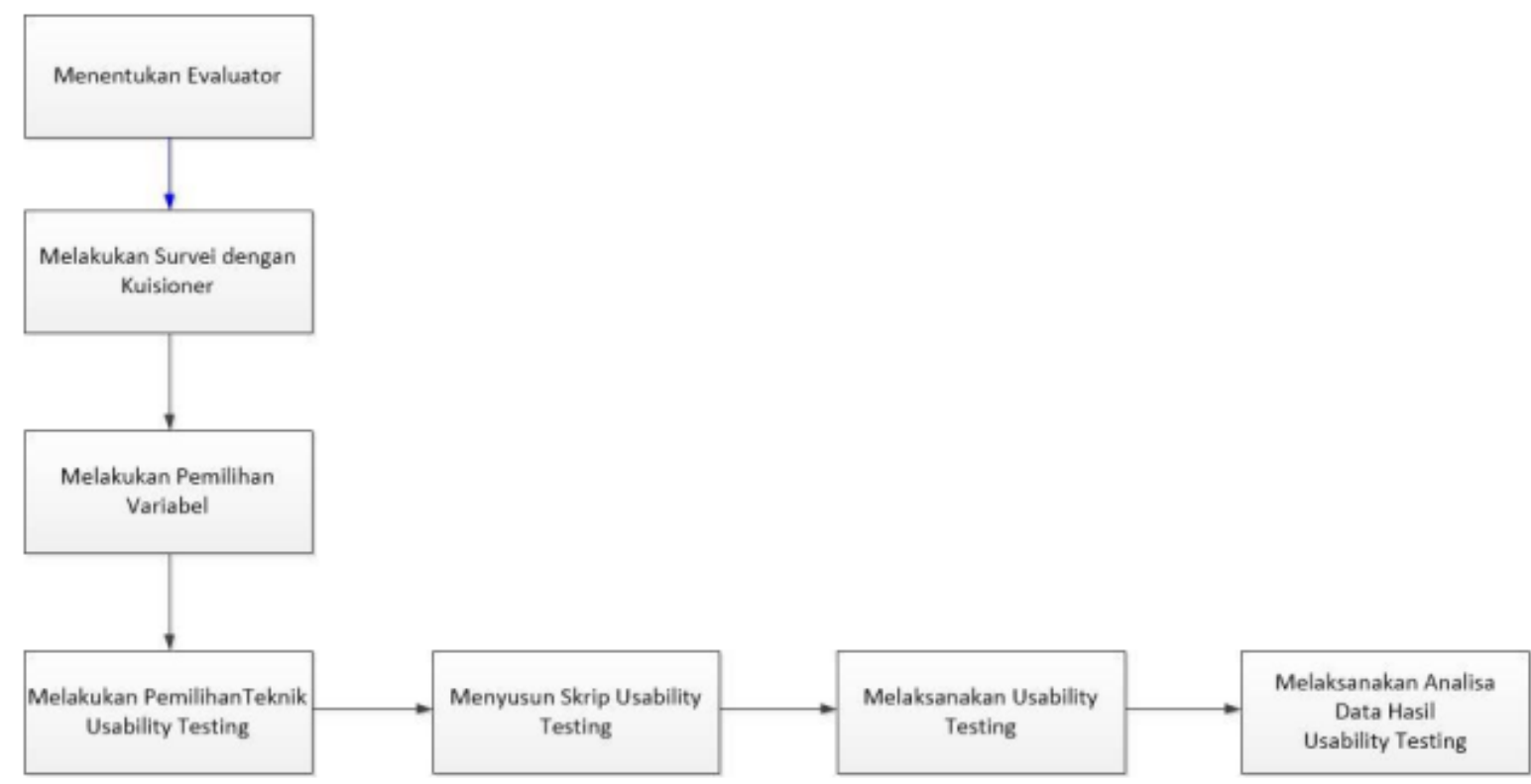

Gambar 4. Tahapan proses usability testing

Berdasarkan Gambar 4, maka:

a) Menentukan evaluator

Pada tahap ini dilakukan penentuan evaluator yang menjadi populasi atau objek penelitian dalam pengujian ini adalah masyarakat umum. Pada umumnya terdapat tiga tingkatan pengguna, yaitu Pengguna aktif (pengguna yang terampil dan aktif dalam menggunakan internet), Pengguna terampil (pengguna yang terampil menggunakan internet), dan Pengguna awam (pengguna yang baru tahu internet).

b) Melakukan survei dengan kuisioner

Pada tahap ini dilakukan pemilihan responden yang didasarkan pada isian pertanyaan dan identitas responden. Secara rinci ketiga level pengguna tersebut di ambil dari 3 level pengguna.

c) Melakukan pemilihan fungsi

Pemilihan fungsi dilakukan berdasarkan metode usability testing menurut Jacob Nielsen yang diukur dengan lima kriteria, yaitu: learnability (mudah dipelajari), efficiency (efisiensi), memorability (mudah diingat), errors (kesalahan), dan satisfaction (kepuasan).

d) Membuat tugas usability test

Membuat tugas usability testing yang akan ditanyakan kepada responden yang telah dipilih berdasarkan pemilihan fungsi yang telah ditentukan. Kemudian dibuat skrip agar tugas yang dibuat tidak melebihi 45 menit

e) Menyusun skrip usability test 
Setelah tugas usability test dibuat, maka langkah selanjutnya adalah menyusun skrip yang digunakan sebagai panduan dalam melaksanakan usability test kepada responden yang telah dipilih, menggunakan usability test script dari Steven Krug[10]. Task-task usability testing yang digunakan terdapat pada Tabel 1.

Tabel 1. Task usability testing

\begin{tabular}{|c|l|}
\hline No & \multicolumn{1}{|c|}{ Task / Tugas } \\
\hline 1 & Login ke sistem sebagai user admin \\
\hline 2 & $\begin{array}{l}\text { Mengunjungi halaman artikel dan melihat keseluruhan isinya, kemudian } \\
\text { membagikan artikel ke sosial media }\end{array}$ \\
\hline 3 & Mengisi form pada halaman Buku tamu untuk mengajukan pertanyaan \\
\hline 4 & Mengunjungi halaman download, lalu melakukan unduh file \\
\hline 5 & Melakukan pengiriman informasi dalam website \\
\hline
\end{tabular}

f) Melaksanakan usability test dengan melakukan wawancara

Usability test dilakukan dengan jumlah responden sebanyak tiga orang yang diawali dengan pengerjaan task yang diberikan oleh peneliti kepada respoden awam, respondek aktif dan responden terampil untuk melakukan pengujian pada website profil BP3K Mundu.

g) Melakukan analisa data hasil Usability Test dan survey

Setelah didapatkan hasil dari usability test, maka hasil tersebut akan dianalisa untuk digabungkan dengan hasil dari survei. Lalu melakukan perhitungan prosentase pada task pada "Formulir Uji Ketergunaan" sebagai berikut:

- Perhitungan ini dilakukan dengan merubah kedalam bentuk angka dari setiap jawaban dengan aturan angka 1 (satu) apabila jawaban "bisa ditemukan" atau tanda centang $(\sqrt{ })$ dan angka 0 (nol) diberikan kepada jawaban "tidak bias ditemukan

- Dari setiap point task dihitung prosentasenya, berapa persen yang ketemu dan berapa persen yang tidak ketemu.

- Dari setiap point Task pada setiap subbagian dihitung subtotal prosentasenya.

- Terakhir adalah menghitung total prosentase dari keseluruhan jawaban yang diberikan responden baik dari jawaban yang bisa dijawab dan jawaban yang tidak bisa dijawab

Kuisioner yang diberikan terdiri dari 18 pertanyaan, dan dari 18 pertanyaan tersebut telah cukup untuk mewakili kelima aspek usability. Responden mengisi kuisioner yang sudah dibagikan berdasarkan pengalamannya (apa yang dilihat dan dirasakan) pada saat melakukan task atau tugas-tugas tadi. Setelah dilakukan penyebaran kuisioner yang diberikan pada responden, maka selanjutnya dilakukan perhitungan hasil tabel kuantitatif terhadap kuesioner pada Usability Testing untuk mengukur penggunaan website profil BP3K Mundu yaitu:

Tabel 2. Task usability testing

\begin{tabular}{|l|l|l|}
\hline \multicolumn{1}{|c|}{ Skor } & \multicolumn{1}{c|}{ Kualifikasi } & \multicolumn{1}{c|}{ Hasil } \\
\hline $85-100 \%$ & Sangat baik (SB) & Berhasil \\
\hline $65-84 \%$ & Baik (B) & Berhasil \\
\hline $55-64 \%$ & Cukup (C) & Tidak berhasil \\
\hline $0-54 \%$ & Kurang (K) & Tidak berhasil \\
\hline
\end{tabular}

Dengan perhitungan sebagai berikut:

Nilai : skor/ jumlah reponden

$$
: 100 / 3=33,33
$$

h) Menyusun rekomendasi perbaikan website:

Berdasarkan analisa yang dihasilkan, maka disusun rekomendasi yang tidak ditemukan dalam perbaikan website yang telah di nilai dari 3 responden dengan tingkat level yang berbeda, terutama dari aspek usability. Dari beberapa tugas atau pertanyaan yang diberikan kepada responden terbagi menjadi dua yaitu:

- Berhasil ditemukan 
Untuk proses kemudahan dipelajari (Learnability) diperoleh angka 100\%, efisiensi (Efficiency) diperoleh angka 77,77\%, kemudahan diingat (Memorability) diperoleh angka 66,66\%, tingkat kesalahan (Error) diperoleh angka 100\%, dan tingkat kepuasan (Satisfaction) diperoleh angka 86,66\%.

- Tidak berhasil ditemukan

Sedangkan untuk semua task yang tidak dapat di selesaikan oleh responden adalah sebagai berikut, untuk proses kemudahan dipelajari (Learnability) diperoleh angka 0\%, efisiensi (Efficiency) diperoleh angka 22,22\%, kemudahan diingat (Memorability) diperoleh angka 33,33\%, tingkat kesalahan (Error) diperoleh angka 0\%, dan untuk tingkat kepuasan (Satisfaction) diperoleh angka 13,33\%. Prosentase untuk seluruh task atau pertanyaan yang dapat dikerjakan oleh responden dari setiap aspek adalah $86,22 \%$ dan pertanyaan yang tidak dapat diselesaikan responden adalah $13,77 \%$.

\section{KESIMPULAN}

Berdasarkan hasil penelitian dan pembahasan, maka dapat diambil beberapa simpulan, yaitu: Penelitian ini telah berhasil merancang website profil BP3K Mundu pada tingkat high fidelity dengan memperhatikan aspek pengalaman pengguna, sehingga fitur dan tampilan dapat lebih mudah dimengerti, nyaman pada saat digunakan dan sesuai dengan kebutuhan pengguna. Hasil evaluasi membuktikan bahwa prototipe low fidelity cukup dipahami dan sudah dapat diterima oleh pengguna dengan cukup baik. Dari sisi usability berdasarkan hasil rekapan secara keseluruhan, website profil BP3K Mundu sudah memenuhi kebutuhan usability yang sangat baik, banyak percobaan yang berhasil dilakukan responden dengan nilai $86,22 \%$ pertanyaan mampu di jawab, dan $13,77 \%$ pertanyaan yang tidak dapat terjawab.

\section{SARAN}

Adapun saran yang dapat dijadikan pertimbangan untuk pengembangan penelitian selanjutnya yaitu: Pelaksanaan usability testing secara kontinyu dan terprogram, sehingga akan memudahkan pengguna dalam mengakses website BP3K Mundu. Serta Pengujian dilakukan menggunakan pengujian usability lain serta metode pengujian UX yang berbeda untuk mendapatkan perbandingan hasil dari pengujian tersebut

\section{DAFTAR PUSTAKA}

[1] Muhammad. Wildan. "Perancangan User Experience Mahasiswa pada Repository Institusi IPB Berbasis Mobile Menggunakan Metode Lean UX". Skripsi, Fakultas Matematika dan Ilmu Pengetahuan Alam Institut Pertanian Bogor 2017 [Online]. Available : https://repository.ipb.ac.id/jspui/handle/123456789/89696

[2] Siska. "E-Agriculture Pengembangan Aplikasi KMS Kedelai Berbasis Mobile Menggunakan Pendekatan UX". Thesis. Sekolah Pascasarjana Institut Pertanian Bogor 2016 [Online]. Available : https://repository.ipb.ac.id/handle/123456789/82741

[3] Leonardo. Kristiani, Endah. "Analisis dan Perancangan Website Profil Perusahaan Therapie Dengan Metode User Experiance". Jurnal Teknik dan Ilmu Komputer Vol.04 No.15 Juli - September 2015 [Online]. Available : http://ejournal.ukrida.ac.id/ojs/index.php/TIK/article/download/1090/1249

[4] Yeskasafitri, Annisa dkk. "Perancangan Model User Interface untuk Website E- 
Commerce Liliput Edu Toys dengan Metode Paper Prototyping". E Proceeding of Engineering Vol.02 No.01 April 2015 [Online]. Available : https://openlibrary.telkomuniversity.ac.id/home/epublication/id/31.html

[5] Prasetyadi, A, dkk. "Pengembangan Aplikasi Repository Karya Ilmiah LIPI Berbasis Mobile". Jurnal Penelitian POS dan Informatika (JPPI) Vol.07 No.01 2017 [Online]. Available https://www.researchgate.net/publication/320398558 Pengembangan_Aplikasi Reposito ri_Karya_Ilmiah_LIPI_Berbasis_Mobile_Development_of_Scientific_Paper_LIPI_Repos itory Mobile Application

[6] Hussain, Azzam. Emmanuel O.C.M. "The Effect Of Responsive Web Design On The User Experiance With Laptop And Smartphone Device". Jurnal Teknologi (Sciences \& Engineering) $\quad 77: 4 \quad 2015 \quad$ [Online]. Available http://repo.uum.edu.my/17467/1/JT\%2077\%204\%20\%2041\%E2\%80\%9347.pdf

[7] Lestari, DM. Dadan Hardianto. AN Hidayanto. "Analysis Of User Experiance Quality On Responsive Web Design From Its Informative Perspective". International Journal of Software Engineering and Its Application Vol.08 No.5 2014 [Online]. Available : http://citeseerx.ist.psu.edu/viewdoc/download;jsessionid=248DC8E7E5B96614D5CC3F6 098968354?doi=10.1.1.636.3822\&rep=rep1\&type $=$ pdf

[8] Garrett, JJ. "The Elements of User Experiance: User Centered Design for the web and beyond. 2nd Edition". E-book from pearson education with printed and bound in United States of America [Online]. Available : http://ptgmedia.pearsoncmg.com/images/9780321683687/samplepages/0321683684.pdf

[9] Beaird, Jason. "The Principles of Beautiful Web Desain Second Edition". E Book From SitePoint Pty Ltd [Online]. Availabel: https://doc.lagout.org/programmation/Design/The\%20Principles\%20of\%20Beautiful\%20 Web\%20Design\%20-\%20Beaird\%20-\%20Site\%20Point\%20\%282010\%29\%20.pdf

[10] Saputra, Eko. Zainal Mazalisa. Ria Andryani. "Usability Testing untuk mengukur penggunaan website inspektorat kota Palembang". Jurnal Teknik Informatika Universitas
Bina
Darma
Palembang
[Online].
Available

http://eprints.binadarma.ac.id/2040/1/Jurnal_Eko\%20Saputra.pdf 